\title{
Investigation of the Ginning Process on ДП Series Saw Gin Stands
}

\author{
Khamit Axmedxodjayev, Akmal Umarov, Kamola Ortiqova \\ Namangan Institute of Engineering and Technology, Namangan, Uzbekistan \\ Email: kamola9090@inbox.ru
}

How to cite this paper: Axmedxodjayev, K., Umarov, A. and Ortiqova, K. (2019) Investigation of the Ginning Process on ДП Series Saw Gin Stands. Engineering, 11, 523-530. https://doi.org/10.4236/eng.2019.118036

Received: June 21, 2019

Accepted: August 26, 2019

Published: August 29, 2019

Copyright () 2019 by author(s) and Scientific Research Publishing Inc. This work is licensed under the Creative Commons Attribution International License (CC BY 4.0).

http://creativecommons.org/licenses/by/4.0/

\begin{abstract}
The article describes the research process of ginning, conducted at the stand of the saw gin of the DP series. The analysis of the roll box of saw gins of different companies was carried out, given the results of studies to determine the speed and density of the seed roll in the roll box of the saw gin. A diagram is given for the dependence of the speed of the feed rollers on the incoming signal.
\end{abstract}

\section{Keywords}

Seed Cotton, Ginning of Cotton, Saw Gin Stand, Roll Box, Seed Roll, Profile of the Roll Box, Speed of the Feed Rolls, Density of the Seed Roll

\section{Introduction}

The roll box is one of the main working organs of the saw gin stand, and the shape, density, speed of the seed roll, the productivity of the machine, the quality of the fiber and seed produced, the energy consumption, etc., depend on its profile. The profiles of the roll box of the "ДП" series saw gin stand (Figure 1) [1], produced in Uzbekistan, and the roll box of saw gin stand produced by American manufacturers were analyzed (Figure 2) [2]. In this case, the seed roll in the roll box is conditionally divided into 3 sections: 1 ) the arc from the entry point of seed cotton into the roll box to the point of contact with the saw, 2) the arc of contact with the saw, 3) the arc from the saw to the entry point of the seed cotton. The results of the measurements are given in Figure 3.

According to the diagrams and the table, the following differences in the profiles of the American roll box from Uzbek saw gin stands are visible:

- there is no section of the arc from the input of seed cotton to the saw, raw materials are fed directly to the saws; 


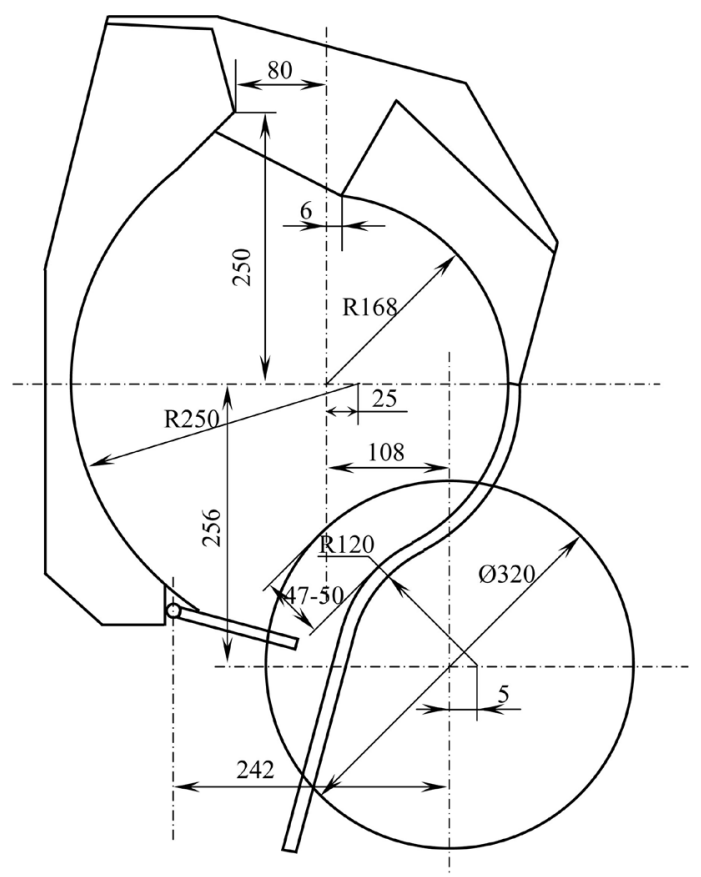

Figure 1. Diagram of the profile of the roll box of the “ДП” series saw gin stand.

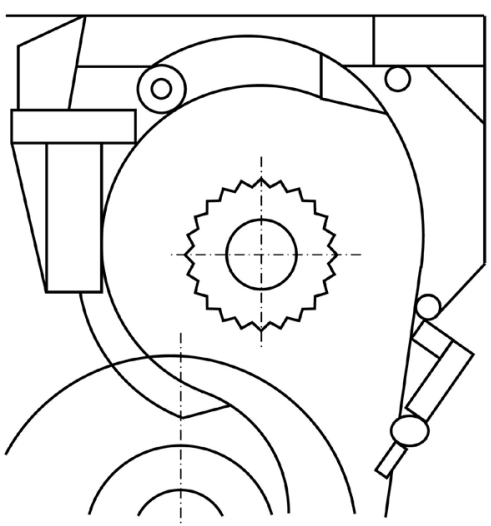

(a)

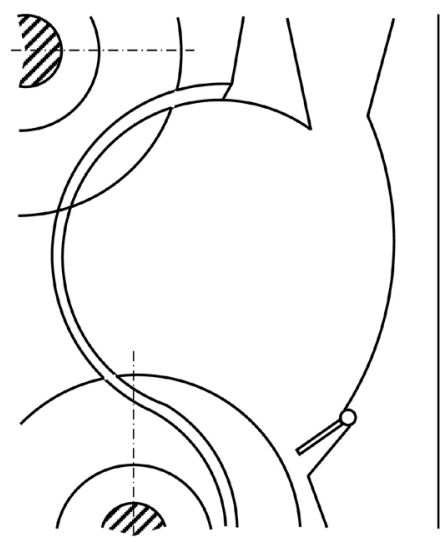

(b)

Figure 2. Diagrams of profiles of roll box of saw gin stand produced by American companies ((a) Gin of Consolidated Cotton Gin Co. Inc.; (b) Hardwicke-Etter Regal 224).

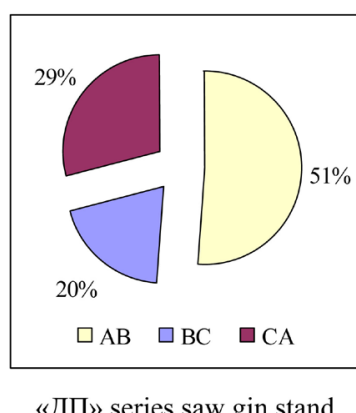

«ДП» series saw gin stand

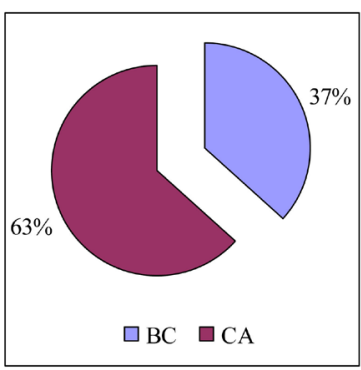

Gin stand of Consolidated Cotton Gin Co. Inc.

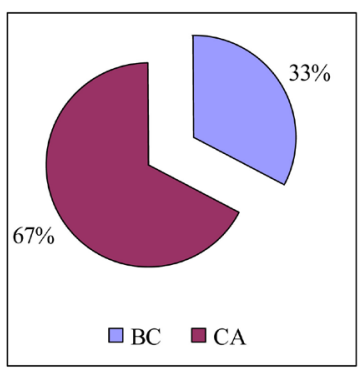

Hardwicke-Etter Regal 224 gin stand

Figure 3. The share of the saw section to the total length of the roll box on various saw gin stands. 
- the perimeter $(1250 \mathrm{~mm})$ of the seed roll in the “ДП" roll box exceeds the perimeter $(1166 \mathrm{~mm}$ and $1019 \mathrm{~mm}$ ) of the roll boxes of American gins (more by $7 \%$ of the roll box of the Consolidated Cotton Gin Co. Inc. gin stand and $18.5 \%$ of the roll box of the Hardwicke Etter Regal 224 gin stand);

- the proportion of the arc of contact between the seed roll and the saw to the total perimeter of the seed roll of American gin stands (respectively 34\% and $27 \%$ vs. $20 \%$ ) is comparatively larger.

The results of the analysis showed that further improvement of the profile of the roll box will improve the quality of fiber and seeds, increase the productivity of the machine and reduce power consumption.

A literary review of saw ginning showed that the speed $V_{\text {seed roll }}$ of a seed roll created in gin stand varies in different areas of the roll box. That is, in the $B C D$ region the speed $V_{B C D}$ of the seed roll is 4 - 5 times less than the speed $V_{\text {saw cylinder }}$ of the saw cylinder (Figure 4).

According to theoretical research G. I. Miroshnichenko, if we take the speed of the seed roll in the grate work zone ( $A$ point) equal to $100 \%$, then the speed at the $D$ point will be $130 \%-160 \%$, at the $B$ point $102 \%-103 \%$, and in the contact zone of the seed roll with the saw-220\% - 230\%.

In order to study the above-mentioned theoretical studies, an experiment was carried out on а “ДП” 30-saw gin stand installed in the laboratory of the Institute NamIET. The cross section of the saw gin stand is the same as the gin stand used in production, but the number of saws is reduced from 130 to 30 . To assess the process occurring in the roll box, a sidewall of plexiglas is installed from the side, and seed cotton, colored red (Figure 5), was used to determine the trajectory of the seed roll.

The results of the experiments were filmed on video, processed in the computer program EDIUS 6 for division into frames. The lengths of the roll box zones were preliminarily measured. The experiments were repeated 3 times and their results were processed in the Excel program (Table 1). The speed of the

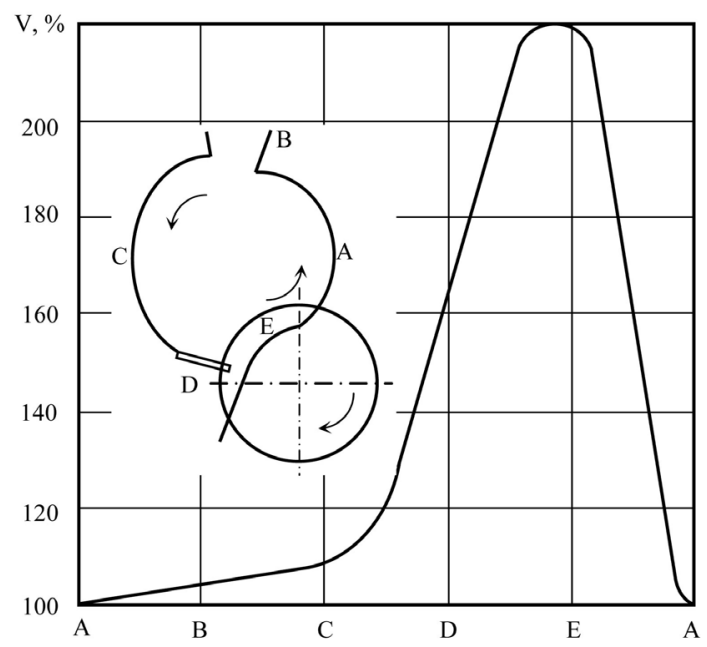

Figure 4. Distribution of the speed of a seed roll along the profile of the roll box according to G. I. Miroshnichenko. 


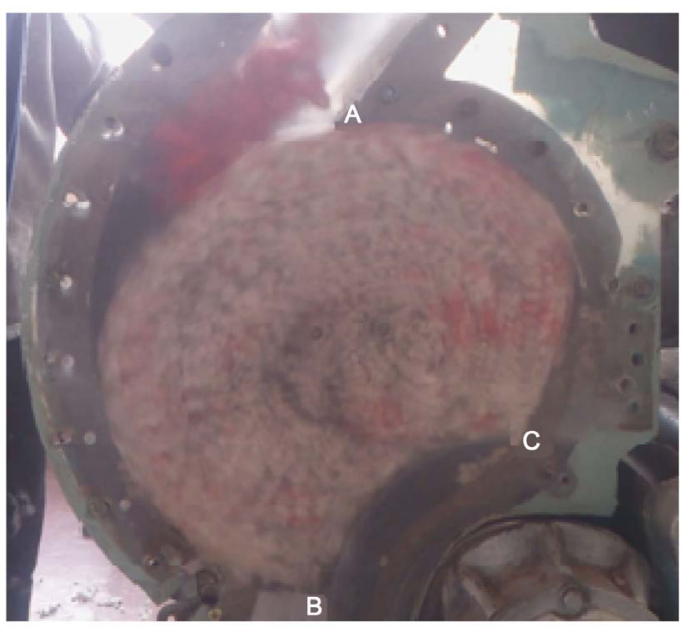

Figure 5. Photo of the roll box and the designation of the areas of the seed roll.

Table 1. Effect of raw speed cushion on the quality of raw materials.

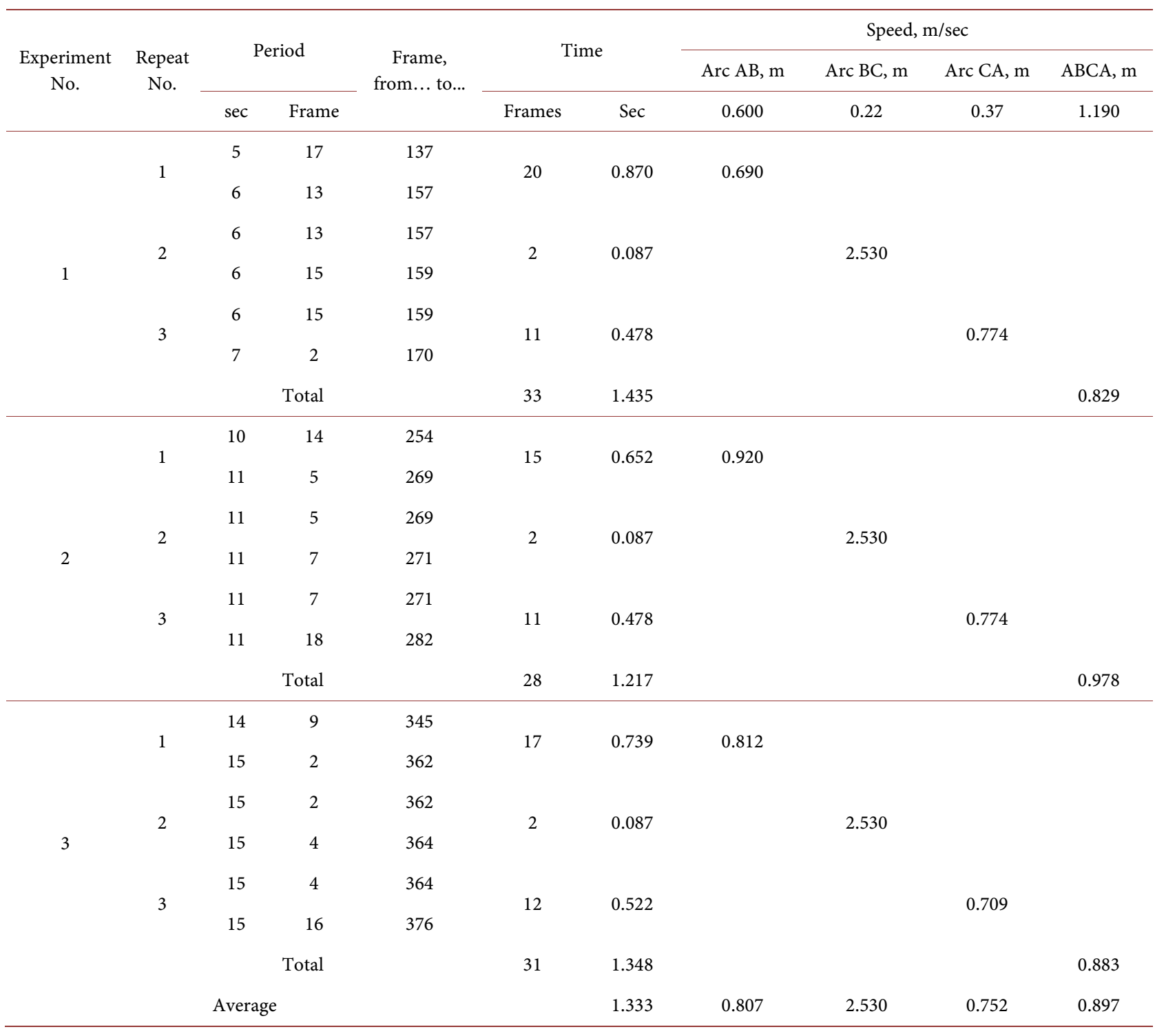


seed roll cushion in the $C A$ zone was adopted as $V_{C A}=100 \%$. At the same time, the speed of the seed roll in the $A B$ zone was $V_{A B}=107 \%$, and in the $B C$ zone$V_{B C}=336 \%$ (Figure 6).

When comparing the theoretical studies carried out by G. I. Miroshnichenko with the experimental results carried out by us, it was revealed that the regularity of the change in the velocity of a seed roll in the roll box corresponds, but their proportions differ.

Previously, he assumed that the linear speed of the seed roll in the area of contact with the saw is equal to the linear speed of the saw $(12 \mathrm{~m} / \mathrm{sec})$. When analyzing the results of experimental studies (Table 1 and Figure 6), it was found that the linear speed of the seed roll in the contact zone $B C$ with the saw is 5 times smaller than the accepted G. I. Miroshnichenko.

This leads to the conclusion that the process of separating the fiber from the seed occurs not only at the $C$ point of contact between the saw and the grate (Figure 4), as was the case in the studies to date, but over the whole $B C$ contact zone of the seed roll with the saw. This explains the increase in the proportion of the contact zone of the seed roll with the saw in relation to the total perimeter of the roll box of American gin stands. Consequently, with further improvement of the saw gin stand, in particular the roll box, it is necessary to take into account the increase in the share of the contact zone of the seed roll with the saw in relation to the "not the ginning" zone of the roll box.

As is known, the main process in the cotton processing industry is the separation of fiber from seed-ginning. Currently, in the factories of Central Asia, are used saw gin stands 4ДП-130, 5ДП-130 and ДПЗ produced in Uzbekistan.

The quality of fiber and seed, the productivity of the machine, the longevity of the working organs largely depends on the density of the seed roll. The productivity of the machine is directly proportional to the density of the seed roll and the quality indices of fiber and seeds are inversely proportional to the density.

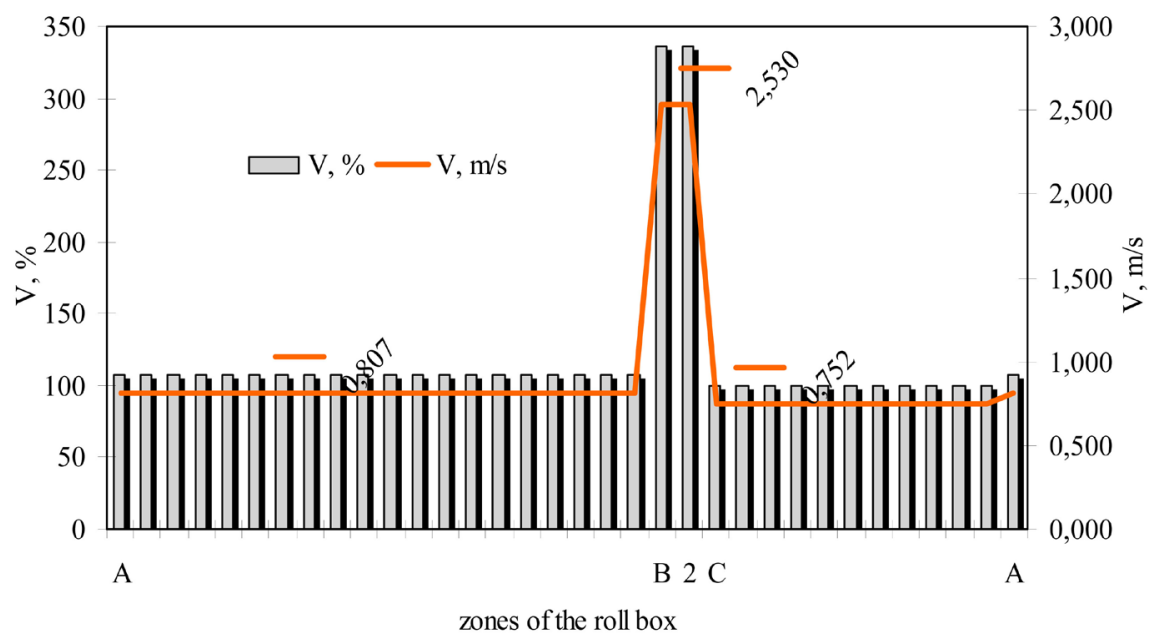

Figure 6. Experimental results of the change in the speed of a seed roll along the profile of the roll box. 
B. I. Bekmirzayev obtained experimental data on the dependence of the density of a seed roll on fiber quality [3]. Proceeding from them, the least damage to the fiber for the I-grade of seed cotton is the density of the seed roll equal to 325 $\mathrm{kg} / \mathrm{m}^{3}$, and for the III-grade- $290 \mathrm{~kg} / \mathrm{m}^{3}$.

In order to determine the density of the seed roll in the roll box, an experiment was carried out at the "ДП" 30 -saw gin stand installed in the laboratory of the Institute NamIET.

The experiment was carried out on seed cotton of the selection variety $\mathrm{Na}$ mangan-77, wetness $9 \%$ and dirtiness $2 \%$. The number of replicates of the experiment is three. The results of the experiment are shown in Table 2 [4].

When determining the density of a seed roll, it was necessary to determine the volume of the roll box. To do this, we used the graphical program Google Sketch Up (you can use other programs, such as Solid Works, Creo, etc.). The cross-sectional area of the roll box was $S=0.11 \mathrm{~m}^{2}$ (Figure 7), and the length was previously measured and equal $L=0.53 \mathrm{~m}$. The volume of the roll box was determined by the following formula

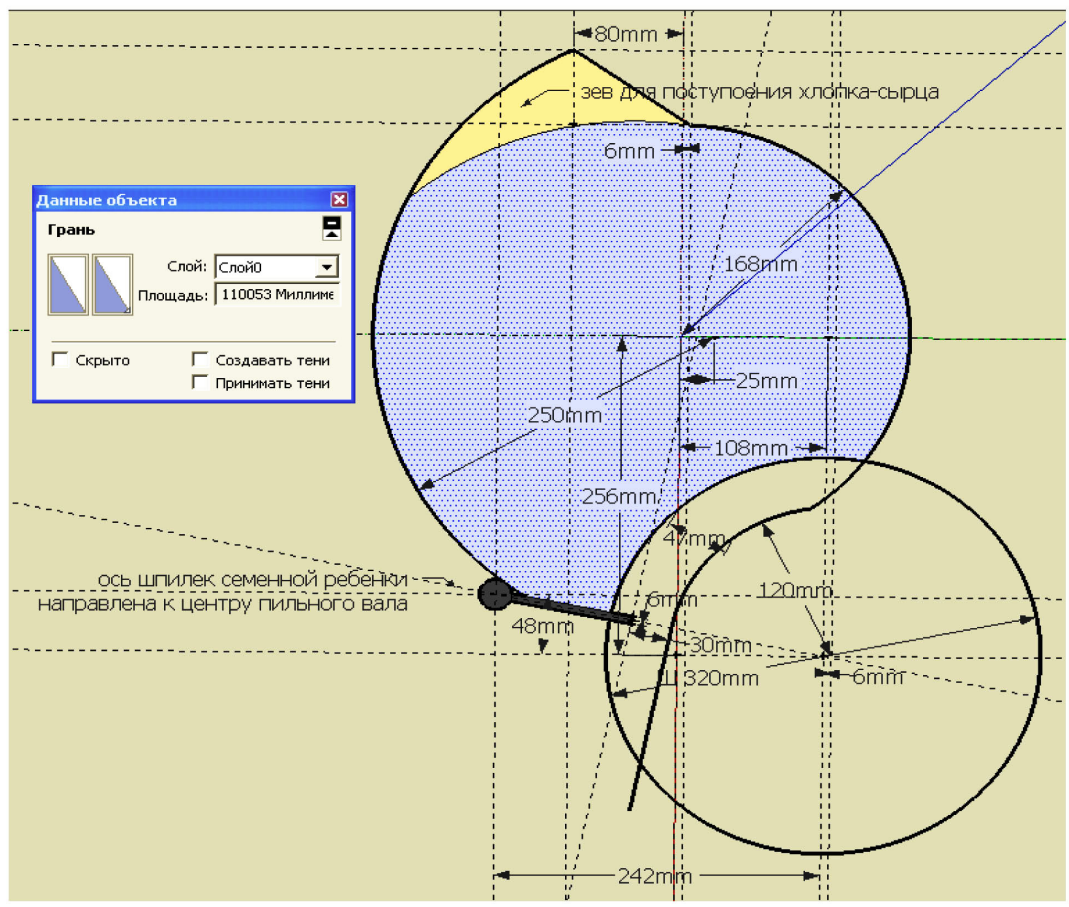

Figure 7. Diagram of the cross-section of the roll box of the “ДП” series saw gin stand.

Table 2. Variation of the density of the raw cushion in the roll box of the Gin.

\begin{tabular}{ccccc}
\hline Repeat No. & $\begin{array}{c}\text { Mass of the } \\
\text { seed roll M, gr }\end{array}$ & $\begin{array}{c}\text { The volume of } \\
\text { the roll box } \mathrm{V}, \mathrm{m}^{3}\end{array}$ & $\begin{array}{c}\text { Density of the } \\
\text { seed roll } \rho, \mathrm{kg} / \mathrm{m}^{3}\end{array}$ & $\begin{array}{c}\text { Average density } \\
\text { of the seed } \\
\text { roll } \rho, \mathrm{kg} / \mathrm{m}^{3}\end{array}$ \\
\hline 1 & 18,025 & 0.058 & 310.8 & \\
2 & 19,105 & 0.058 & 329.4 & 315.9 \\
3 & 17,840 & 0.058 & 307.6 & \\
\hline
\end{tabular}




$$
V=S \cdot L=0.11 \times 0.53=0.058 \mathrm{~m}^{3}
$$

During the experiment the working gin stand was stopped, the seed roll was piled out and weighed on the electronic scales. To determine the density of the seed roll, the following formula was used

$$
\rho=\frac{m}{V}
$$

When researching processes in equipment, there is a need to determine and change the speeds, loads, operating time and other indicators of working organs [5].

In saw gin stand, the speed of feed rolls changes in order to regulate the density of the seed roll. We suggested changing the speed of feed rolls by a frequency inverter. Another advantage of using a frequency inverter is the possibility of observing certain indicators of working organs during the work.

In order to study the changes in the parameters of feed rolls as a result of adjusting their speed, experiments were conducted at the 30-saw gin stand in the laboratory of institute NamIET [6].

In the experiment, was used a Danfoss VLT frequency inverter, which was connected to the computer with a standard USB cable. The program MST 10, developed by Danfoss, was also used.

As can be seen from the graph (Figure 8), when the signal coming to the frequency inverter (yellow line) changes, the speed of the feed rolls (blue line) changes synchronously. This shows the possibility of using a frequency inverter as a regulator of the mass of seed cotton entering the roll box of the saw gin stand.

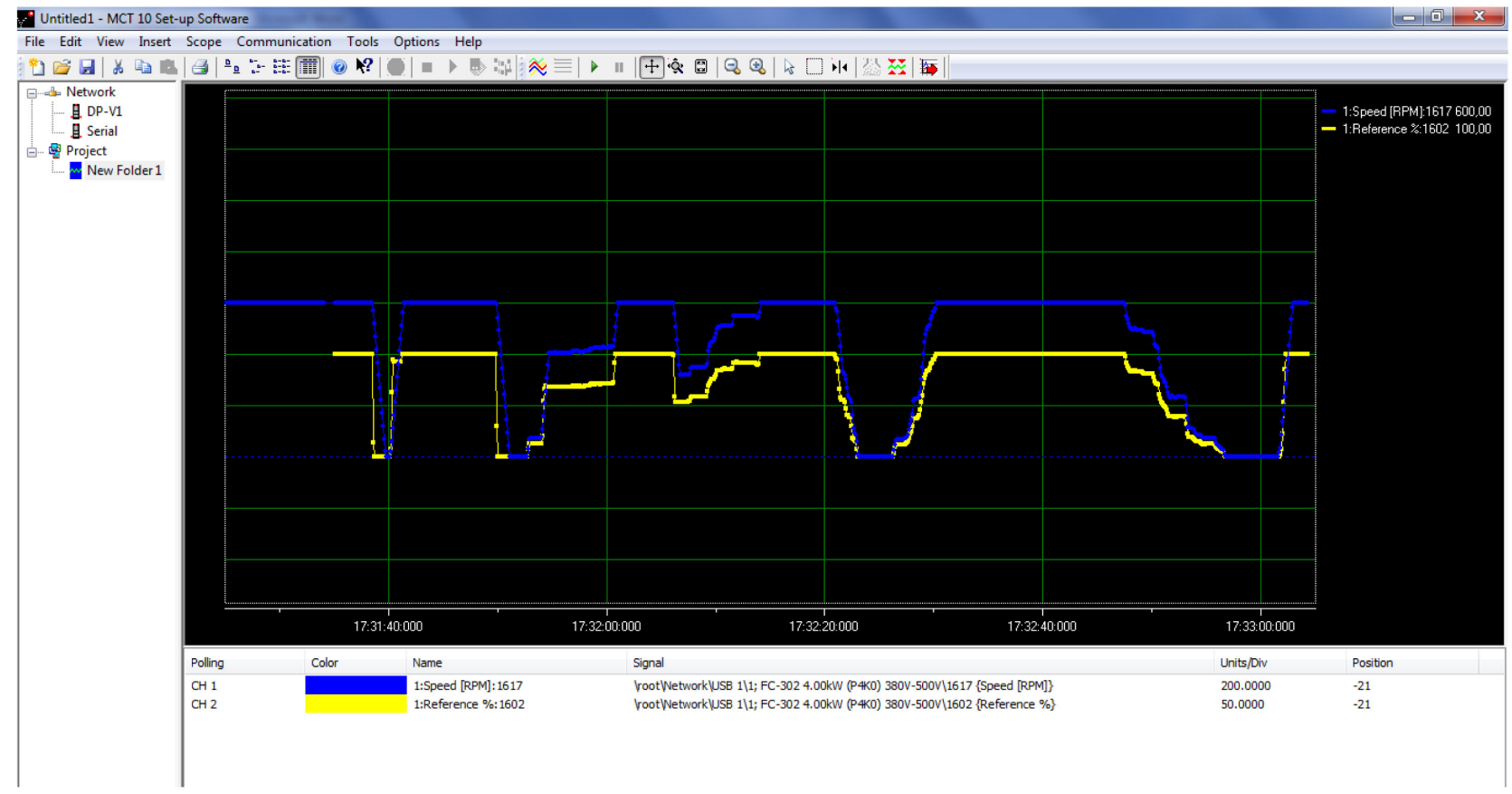

Figure 8. The diagram of the change in the value of the signal coming to the frequency inverter (yellow line) and the speed of the feed rolls (blue line) over time in the program MST 10. 
In the MCT 10 program, it is possible to select parameters such as the maximum and minimum motor speed, the frequency of the current, the magnitude of the input and output signals, and so on. Also, using the oscilloscope function, it is possible to create, download and save new projects [7] [8]. This function allows you to monitor the current changes in real time. For a complete analysis of the process, the results can be saved in Excel as a table [9].

\section{Conclusions}

1) The analysis of profiles of roll box of the saw gin stands of different companies is carried out.

2) The results of studies on determining the speed and density of the seed roll in the roll box of the saw gin stand are given.

3) The diagram of the dependence of the speed of the feed rolls on the incoming signal is obtained.

\section{Conflicts of Interest}

The authors declare no conflicts of interest regarding the publication of this paper.

\section{References}

[1] Miroshnichenko, G.I. (1972) Basics of Designing Cotton Ginning Machines. Mashinostroenie, Moscow, 480.

[2] Anthony, W.S. and Mayfield, W.D. (1994) Cotton Ginners Handbook. Agricultural Handbook 503, U.S. Department of Agriculture, Washington DC, 90.

[3] Bekmirzaev, B.I. (1989) Development of a Method for Regulating the Feeding of Saw Gin Stand by the Air Permeability of a Seed Roll in Order to Improve the Quality of Fiber and Seeds. Diss. Cand. Tech. Sciences, Tashkent, 6-58.

[4] Ahmedkhodzhaev, Kh.T., Umarov, A.A., Mirgulshanov, K. and Ortiqova, K. (2016) Determination of the Density of a Seed Roll. Namangan, 6-7.

[5] Ortiqova, K., Mirgulshanov, K., Tojiboyev, M. and Umarov, A.A. (2016) Study of the Composition of a Seed Roll in the Roll Box of Gin. Namangan, 179-181.

[6] Abduvakhidov, M., Umarov, A.A. and Kenzhaeva, M. (2016) Experimental Determination of the Speed of a Seed Roll. Namangan, 175-176.

[7] Obidov, A., Akhmedkhodjaev, Kh., Sarimsakov, O. and Holikov, Q. (2018) Investigation of the Properties of Fibrous Cotton Seeds, for Sorting on a Mesh Surface. The Journal of Engineering, 10, 572-578. https://doi.org/10.4236/eng.2018.109041

[8] Abdukarimovich, M.O., Ibragimovich, A.K. and Sharipjanovich, S.O. (2018) Designing a New Design of a Loading Cylinder for Pneumomechanical Spinning Machines. Engineering, 10, 345-356. https://doi.org/10.4236/eng.2018.106025

[9] Umarov, A.A., Abduvakhidov, M., Sharipov, Kh. and Mirgulshanov, K. (2016) Analysis of the Profile of the Working Chamber of Saw Gin. Namangan, 176-178. 